\title{
GAMBARAN TINDAKAN PEMELIHARAN KESEHATAN GIGI DAN MULUT ANAK USIA 10 - 12 TAHUN DI SD KRISTEN EBEN HAEZAR 02 MANADO
}

\author{
${ }^{1}$ Chrisdwianto Sutjipto \\ ${ }^{2}$ Vonny N.S Wowor \\ ${ }^{2}$ Wulan P.J Kaunang \\ ${ }^{1}$ Kandidat Skripsi Program Studi Kedokteran Gigi \\ ${ }^{2}$ Program Studi Kedokteran Gigi Fakultas Kedokteran Universitas Sam Ratulangi \\ Email: ch_121_s@yahoo.com
}

\begin{abstract}
Abstrak: Pemeliharaan kesehatan gigi dan mulut sangat erat hubungannya dengan perilaku dan untuk mengubah perilaku dibutuhkan peran serta masyarakat dimana individu berada. Lingkungan terdekat di mana individu berada yaitu lingkungan keluarga dan lebih luas lagi yaitu lingkungan sekolah. Pengetahuan dan pendidikan yang diberikan orang tua dan guru sangat membantu pembentukan perilaku anak. Usia anak sekolah dasar yaitu berkisar 6-12 tahun. Dimana kesadaran untuk memelihara kesehatan mulut yang masih kurang tanpa adanya dukungan dari orang tua untuk membiasakan menyikat gigi 2 kali sehari, jika kesehatan mulut tidak dapat dijaga, dampaknya akan sangat merugikan. Penelitian ini bertujuan untuk mendapatkan data tentang tindakan pemeliharaan kesehatan gigi dan mulut anak usia 10-12 tahun. Penelitian ini bersifat deskriptif, dan teknik pengambilan sampel yang digunakan adalah total sampel pada 150 siswa. Hasil penelitian menunjukkan gambaran tindakan pemeliharaan kesehatan gigi dan mulut anak usia 10 - 12 tahun baik yaitu 74,93\% dengan tindakan pemeliharaan kebersihan gigi dan mulut baik yaitu 82,88\%, tindakan pola konsumsi makanan tergolong baik yaitu 68,22\%, demikian juga dengan tindakan peningkatan kesehatan gigi dan mulut yang tergolong baik yaitu 76,67\%.
\end{abstract}

Kata kunci: Tindakan pemeliharaan, kesehatan gigi dan mulut anak.

\begin{abstract}
Dental health care is very closely related with behavior and to change the behavior we need participation of society where the person are. Nearest environment of the person is family environment and wider is school environment. Knowledge and education provided parents and teachers helps the formation of children's behavior. Elementary school children ranging 6-12 years. Where to maintain oral health awareness is still lacking without the support of parents to familiarize brushing 2 times a day, if oral health can not be maintained, impact would be extremely detrimental. This study aimed to obtain data on measures of oral health care children aged 10-12 years. This research is descriptive, and the sampling technique used is the total sample at 150 students. The results show an overview of action of oral health care children aged 10 - 12 years was good with 74,93\% with dental clean care was good with $82,88 \%$, diet was good with $68,22 \%$, and step up of dental health care was good with $76,67 \%$.
\end{abstract}

Keywords: Dental health care, child oral health.

Pembangunan kesehatan bertujuan meningkatkan kesadaran dan kemampuan hidup sehat bagi setiap orang agar terwujud derajat kesehatan yang optimal meliputi kesehatan fisik, mental dan sosial. Untuk mewujudkan hal tersebut, maka dilakukan pendekatan lewat upaya pemeliharaan dan peningkatan kesehatan (promotif), pencegahan penyakit (preventif), penyembuhan penyakit (kuratif) dan pemulihan kesehatan 
(rehabilitatif) yang dilakukan secara menyeluruh dan berkesinambungan. ${ }^{1,2}$

Data World Health Organisation (WHO) tahun 2005 menunjukkan bahwa 90\% dari jumlah anak di dunia mengalami masalah kerusakan gigi. Hasil Riset Kesehatan Dasar (Riskesdas) 2007, karies gigi diderita oleh $72,1 \%$ penduduk Indonesia dan dalam 12 bulan terakhir sebanyak 23,4\% penduduk Indonesia mengeluhkan adanya masalah pada gigi dan mulutnya. Dari jumlah tersebut, hanya $29,6 \%$ yang mencari pertolongan dan mendapatkan perawatan dari tenaga kesehatan. Hal ini mengindikasikan masih rendahnya tingkat kesadaran dan tingkat utilisasi masyarakat terhadap pelayanan kesehatan gigi. Masih menurut riset tersebut, 91,1\% masyarakat Indonesia yang berumur di atas 10 tahun, meskipun sudah menggosok gigi setiap hari, namun hanya sebesar $7,3 \%$ yang telah menggosok gigi secara benar, yaitu pagi setelah sarapan dan malam sebelum tidur. Sedangkan menurut penelitian yang dilakukan Unilever ditahun 2007, hanya terdapat 5,5\% masyarakat Indonesia yang memeriksakan kesehatan gigi secara teratur ke dokter gigi. ${ }^{3,4}$

Periode 6-12 tahun merupakan masa usia sekolah dasar, dimana usia $10-12$ tahun merupakan periode gigi bercampur, sehingga diperlukan tindakan yang baik untuk pemeliharaan kesehatan gigi dan mulut. Pada periode ini juga anak sudah menunjukkan kepekaan untuk belajar sesuai dengan rasa ingin tahunya, termasuk menyikat gigi. Oleh karena itu pada usia ini sangat tepat untuk mengajarkan sesuatu hal yang baru kepada anak.

Program menyikat gigi pada anak usia sekolah merupakan suatu tindakan pemeliharaan kesehatan gigi yang dapat mengurangi penyakit gigi dan mulut, seperti periodontitis kronis dan karies. Cara menggosok gigi dengan benar dapat menjaga kesehatan gigi dan mulut. Menurut data riskesdas 2007 sejumlah 91,1\% penduduk umur lebih dari 10 tahun mempunyai kebiasaan menggosok gigi tiap hari, tapi hanya $12,6 \%$ yang menggosok gigi sesudah makan pagi dan $28,7 \%$ sebelum tidur malam. 5,6,7 Hasil ini memberikan gambaran bahwa sebagian besar penduduk masih belum memiliki perilaku yang benar dalam hal menyikat gigi pada waktu yang tepat. Hal ini bisa berdampak pada kesehatan gigi dan mulut yang kurang baik.

Kesehatan gigi dan mulut sangat erat hubungannya dengan perilaku. Perilaku pemeliharaan kesehatan gigi dan mulut yang baik akan sangat berperan dalam menentukan derajat kesehatan dari masingmasing individu. Oleh karena itu perilaku pemeliharaan kesehatan gigi dan mulut yang kurang baik harus diubah. Lingkungan sangat berperan dalam pembentukan perilaku seseorang, di samping faktor bawaan. Lingkungan masyarakat di mana individu itu berada akan ikut berperan dalam pembentukan perilaku seseorang, oleh karena itu untuk mengubah perilaku dibutuhkan peran serta masyarakat dimana individu tersebut berada. Lingkungan terdekat di mana individu berada yaitu lingkungan keluarga dan lebih luas lagi yaitu lingkungan sekolah. Di sini peran orang tua dan guru sangat menentukan dalam melakukan perubahan perilaku dalam pemeliharaan kesehatan gigi dan mulut anak. Pengetahuan dan pendidikan yang diberikan orang tua dan guru sangat membantu pembentukan perilaku anak.

Upaya pemeliharaan kesehatan gigi dan mulut antara lain meliputi tindakan menyikat gigi, kumur-kumur dengan larutan fluor. Tindakan menyikat gigi merupakan hal yang utama dalam upaya pemeliharaan kesehatan gigi dan mulut. Untuk melakukan tindakan ini dibutuhkan kemampuan motorik, dimana usia sekolah dasar merupakan usia yang ideal untuk melatih kemampuan motorik seorang anak. Peran orang tua dan guru dibutuhkan untuk menjelaskan, memberi contoh, membimbing serta mendorong anak untuk memiliki perilaku yang baik dan diharapkan.,

Data riskesdas provinsi Sulawesi Utara tahun 2007 menunjukkan bahwa sebanyak 82,8\% penduduk mempunyai pengalaman karies gigi dengan prevalensi karies aktif 
mencapai 57,2\% dan DMF-T mencapai 5,01\%. Data ini menunjukkan bahwa angka karies masih tinggi, dan angka ini berhubungan erat dengan perilaku pemeliharaan kesehatan gigi dan mulut. Faktor pendidikan memegang peranan penting dalam mengubah perilaku seseorang. Pendidikan kesehatan gigi yang diberikan sejak dini pada anak usia sekolah akan sangat bermanfaat dalam pemeliharaan kesehatan gigi dan mulut. ${ }^{10}$

SD Kristen Eben Haezar 02 merupakan salah satu sekolah dasar favorit yang berada di kota Manado, dimana sebagian besar siswa berasal latar belakang ekonomi menengah ke atas. Pada survei awal yang penulis lakukan ditemukan sebagian siswa memiliki kebersihan mulut yang dapat dikatakan baik. Mengingat masih tingginya angka penyakit gigi dan mulut di Indonesia terutama angka karies gigi yang secara tidak langsung berhubungan erat dengan perilaku memelihara kebersihan gigi dan mulut anak dan di sisi lainnya pendidikan berperan penting dalam mengubah perilaku anak, maka penulis tertarik mengangkat judul "Gambaran Tindakan Menyikat Gigi Anak Usia 10-12 Tahun di SD Eben Haezar 02 Manado Terhadap Kebersihan Mulut“

\section{METODE PENELITIAN}

Jenis penelitian yang digunakan adalah penelitian deskriptif yaitu suatu metode penelitian yang dilakukan dengan tujuan membuat gambaran tentang suatu keadaan secara objektif.

Untuk mendapatkan hasil dari perhitungan kuisioner, pertanyaan diukur menggunakan skala Guttman yaitu setiap pertanyaan diberi skor 2 bila menjawab ya dan diberi skor 1 bila menjawab tidak. Hasil perhitungan ditotal jumlah skornya, selanjutnya dihitung berdasarkan rumus sebagai berikut: ${ }^{11}$

Pengukuran untuk tindakan pemeliharaan kesehatan gigi dan mulut

Tindakan pemeliharaan kesehatan gigi dan mulut diukur terlebih dahulu dengan mengalikan skor maksimal untuk setiap jawaban dengan jumlah pertanyaan serta dikalikan dengan jumlah responden sehingga diperoleh pencapaian skor maksimal dengan persamaan matematika; Skor maksimal $=2 \times 10 \times 150=3000$.

Selanjutnya tindakan pemeliharaan kesehatan gigi dan mulut dapat dirumuskan berdasarkan perhitungan berikut:

$$
\mathrm{X} / 3000 \times 100 \%=\mathrm{Y}
$$

dimana:

$$
\begin{array}{lll}
\mathrm{X} & \text { Jumlah skor subjek penelitian yang } \\
& \begin{array}{l}
\text { diperoleh dari perhitungan jumlah skor } \\
\text { tertinggi }
\end{array} \\
3000 & =\text { Jumlah skor tertinggi responden } \\
100 \% & =\text { Nominal yang digunakan dalam } \\
& \text { perhitungan presentase } \\
\mathrm{Y} & =\text { Hasil perhitungan }
\end{array}
$$

Hasil dari perhitungan tersebut kemudian dikategorikan menjadi 2 kategori dalam skala perhitungan yaitu :

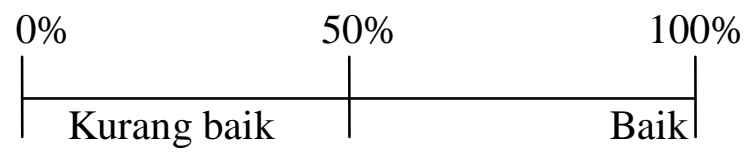

\section{Pengukuran untuk tindakan pemeliharaan kebersihan gigi dan mulut}

Tindakan pemeliharaan kebersihan gigi dan mulut diukur terlebih dahulu dengan mengalikan skor maksimal untuk setiap jawaban dengan jumlah pertanyaan serta dikalikan dengan jumlah responden sehingga diperoleh pencapaian skor maksimal sebagai berikut:

$$
\text { Skor maksimal: 2x4x150 = } 1200
$$

Selanjutnya tindakan pemeliharaan kebersihan gigi dan mulut dapat dirumuskan berdasarkan perhitungan berikut:

$$
\mathrm{X} / 1200 \times 100 \%=\mathrm{Y}
$$

dimana:

$\mathrm{X}=$ Jumlah skor subjek penelitian yang diperoleh dari perhitungan jumlah skor tertinggi

$1200=$ Jumlah skor tertinggi responden

$100 \%=$ Nominal yang digunakan dalam perhitungan presentase

$\mathrm{Y} \quad=$ Hasil perhitungan 
Hasil dari perhitungan tersebut kemudian dikategorikan menjadi 2 kategori dalam skala perhitungan yaitu :

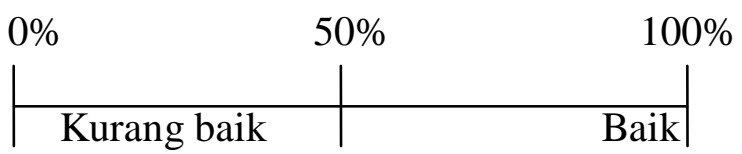

\section{Pengukuran untuk tindakan pola konsumsi makanan}

Tindakan pola konsumsi makanan diukur terlebih dahulu dengan mengalikan skor maksimal untuk setiap jawaban dengan jumlah pertanyaan serta dikalikan dengan jumlah responden sehingga diperoleh pencapaian skor maksimal sebagai berikut:

Skor maksimal: 2x3x150 = 900

Selanjutnya tindakan pola konsumsi makanan dapat dirumuskan berdasarkan perhitungan berikut:

$$
\mathrm{X} / 900 \times 100 \%=\mathrm{Y}
$$

dimana:

$$
\begin{array}{ll}
\mathrm{X} & =\text { Jumlah skor subjek penelitian yang } \\
& \text { diperoleh dari perhitungan } \\
& \text { jumlah skor tertinggi } \\
& =\text { Jumlah skor tertinggi responden } \\
900 & =\text { Nominal yang digunakan } \\
100 \% & \text { perhitungan presentase } \\
\mathrm{Y} & =\text { Hasil perhitungan }
\end{array}
$$

Hasil dari perhitungan tersebut kemudian dikategorikan menjadi 2 kategori dalam skala perhitungan yaitu:

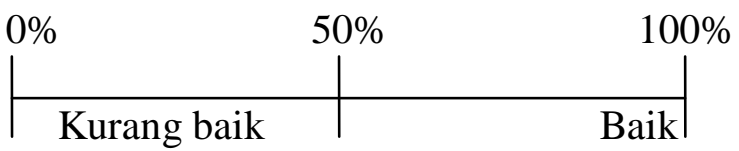

\section{Pengukuran untuk tindakan pening- katan kesehatan gigi dan mulut}

Tindakan peningkatan kesehatan gigi dan mulut diukur terlebih dahulu dengan mengalikan skor maksimal untuk setiap jawaban dengan jumlah pertanyaan serta dikalikan dengan jumlah responden sehingga diperoleh pencapaian skor maksimal sebagai berikut:
Skor maksimal: 2x3x150 $=900$

Selanjutnya tindakan peningkatan kesehatan gigi dan mulut dapat dirumuskan berdasarkan perhitungan berikut:

$$
\begin{array}{ll}
\text { dimana: } & \mathrm{X} / 900 \mathrm{x} 100 \%=\mathrm{Y} \\
\mathrm{X} & =\text { Jumlah skor subjek penelitian yang } \\
& \begin{array}{l}
\text { diperoleh dari perhitungan jumlah } \\
\text { skor tertinggi }
\end{array} \\
900 \quad \text { = Jumlah skor tertinggi responden } \\
100 \% & =\text { Nominal yang digunakan dalam } \\
\text { Y } & \text { perhitungan presentase }
\end{array}
$$

Hasil dari perhitungan tersebut kemudian dikategorikan menjadi 2 kategori dalam skala perhitungan yaitu :

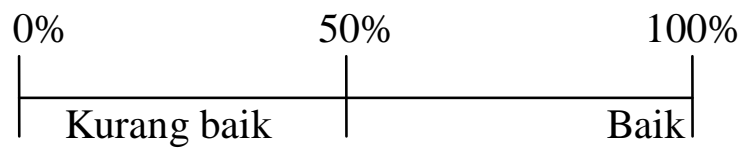

\section{HASIL PENELITIAN}

Hasil penelitian berupa data tentang tindakan pemeliharaan kesehatan gigi dan mulut siswa SD Kristen Eben Haezar 02 Manado yang meliputi tindakan pemeliharaan kebersihan gigi, pola konsumsi makanan, dan tindakan peningkatan kesehatan gigi, sebagai berikut:

\section{Tindakan pemeliharaan kebersihan gigi}

Tindakan pemeliharaan kebersihan gigi dimaksud pada penelitian ini meliputi frekuensi dan waktu menyikat gigi, cara menyikat gigi serta tindakan menjaga kebersihan gigi dan mulut setelah mengonsumsi makanan manis, sebagai berikut:

\section{Frekuensi dan waktu menyikat gigi}

Frekuensi menyikat gigi dilihat dari berapa kali dalam sehari para siswa melakukan tindakan menyikat gigi, sedangkan waktu menyikat gigi dilihat dari kapan tindakan menyikat gigi dilakukan 
oleh para siswa tersebut. Tindakan tersebut dilakukan sebelum makan atau setelah makan.

Hasil penelitian menunjukkan bahwa dari 150 subjek penelitian, terdapat sejumlah 77 siswa (51,3\%) yang menyikat gigi dua kali dalam sehari pada waktu pagi sesudah sarapan dan malam sebelum tidur, dan 73 siswa $(48,6 \%)$ tidak menyikat gigi secara teratur.

\section{Cara menyikat gigi}

Hasil penelitian tentang cara menyikat gigi, meliputi jenis gerakan menyikat gigi yang dilakukan serta permukaan yang disikat:

Hasil penelitian menunjukkan dari 150 subjek penelitian, terdapat sejumlah 123 siswa (82\%) yang menyikat gigi dengan gerakan kombinasi (atas-bawah, majumundur, memutar), dan 27 siswa (18\%) yang menyikat gigi dengan gerakan yang tidak menentu.

Hasil penelitian menunjukkan dari 150 subjek penelitian, terdapat sejumlah 130 siswa $(86,66 \%)$ yang menyikat gigi diseluruh permukaan gigi, dan 20 siswa $(13,33 \%)$ yang menyikat gigi tidak pada seluruh permukaan.

\section{Tindakan menjaga kebersihan gigi dan mulut setelah mengonsumsi makanan manis}

Hasil penelitian berupa data tentang tindakan yang dilakukan setelah mengonsumsi makanan manis dapat dilihat pada tabel 5 di bawah ini.

Hasil penelitian berdasarkan menunjukkan bahwa dari 150 subjek penelitian, terdapat sejumlah 64 siswa (42,66\%) yang melakukan tindakan menyikat gigi atau berkumur, dan 86 siswa (57,33\%) yang tidak melakukan tindakan apa-apa setelah makan makanan manis.

Data yang diperoleh secara keseluruhan hasil perhitungan tindakan pemeliharaan kebersihan gigi dari siswa SD Kristen Eben Haezar 02 Manado yaitu sebagai berikut: jumlah jawaban benar yang di jawab oleh siswa untuk 4 pertanyaan mengenai tindakan pemeliharaan kebersihan gigi yaitu 994. Maka:

$$
\begin{gathered}
\mathrm{X} / 1200 \times 100 \%=\mathrm{Y} \\
994 / 1200 \times 100 \%=82,88 \%
\end{gathered}
$$

Berdasarkan hasil perhitungan di atas, persentase tindakan pemeliharaan kebersihan gigi siswa SD Kristen Eben Haezar 02 Manado sebesar 82,88\%. Maka dalam penjabaran pada skala perhitungan tindakan pemeliharaan kebersihan gigi siswa SD Kristen Eben Haezar 02 Manado termasuk pada kategori baik

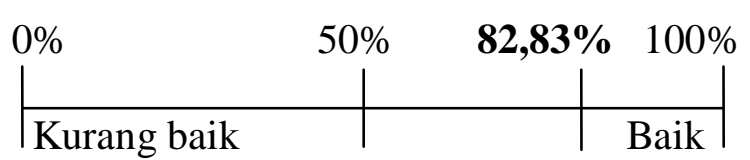

\section{Pola konsumsi makanan}

Hasil penelitian tentang pola konsumsi makanan, meliputi jenis makanan yang dikonsumsi di antara waktu makan dan frekuensi konsumsi makanan yang membantu membersihkan gigi.

Jenis makanan yang dikonsumsi di antara waktu makan meliputi jenis makanan manis, buaha-buahan, serta kombinasi keduanya:

Hasil penelitian menunjukkan dari 150 subjek penelitian, terdapat sejumlah 21 siswa (14\%) yang mengonsumsi buahbuahan, dan 129 siswa (86\%) yang tidak mengonsumsi buah-buahan diantara waktu makan.

Hasil penelitian tentang frekuensi konsumsi makanan yang membantu membersihkan gigi adalah sebagai berikut:

\section{Frekuensi konsumsi buah-buahan}

Frekuensi konsumsi buah-buahan dalam 1 minggu oleh subjek penelitian dapat dilihat pada tabel 6b di bawah ini:

Hasil penelitian menunjukkan bahwa dari 150 subjek penelitian, terdapat sejumlah 63 siswa (42\%) yang mengonsumsi buah-buahan, dan 87 siswa (58\%) tidak sering mengonsumsi buahbuahan. 


\section{Frekuensi konsumsi sayuran}

Hasil penelitian tentang frekuensi konsumsi sayuran oleh subjek penelitian

Hasil penelitian menunjukkan bahwa dari 150 subjek penelitian, terdapat sejumlah 80 siswa $(53,3 \%)$ yang sering mengonsumsi sayuran, dan 70 siswa (46,66\%) yang kurang mengonsumsi sayuran.

Data yang diperoleh secara keseluruhan hasil perhitungan tindakan pola konsumsi makanan dari siswa SD Kristen Eben Haezar 02 Manado yaitu sebagai berikut: jumlah jawaban benar yang di jawab oleh siswa untuk 3 pertanyaan mengenai tindakan pola konsumsi makanan yaitu 614. Maka:

$$
\begin{gathered}
\mathrm{X} / 900 \times 100 \%=\mathrm{Y} \\
614 / 900 \times 100 \%=68,22 \%
\end{gathered}
$$

Berdasarkan hasil perhitungan di atas, persentase tindakan pola konsumsi makanan siswa SD Kristen Eben Haezar 02 Manado sebesar 68,22\%. Maka dalam penjabaran pada skala perhitungan tindakan pola konsumsi makanan siswa SD Kristen Eben Haezar 02 Manado termasuk pada kategori baik.

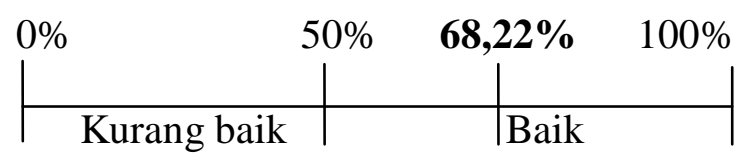

\section{Tindakan peningkatan kesehatan gigi}

Hasil penelitian tentang tindakan peningkatan kesehatan gigi meliputi penggunaan pasta gigi berfluor, frekuensi pemeriksaan rutin ke dokter gigi dalam setahun, tindakan pencarian pertolongan dokter gigi saat sakit, sebagai berikut:

\section{Penggunaan pasta gigi berfluor}

Hasil penelitian tentang tindakan penggunaan pasta gigi mengandung fluor saat menyikat gigi.

Hasil penelitian menunjukkan dari 150 subjek penelitian, didapatkan seluruh siswa (100\%) menyikat gigi menggunakan pasta gigi berfluor.

\section{Frekuensi pemeriksaan rutin ke dokter gigi dalam setahun}

Penelitian untuk mengetahui frekuensi subjek penelitian dalam melakukan tindakan pemeriksaan rutin ke dokter gigi dalam 1 tahun

Hasil penelitian menunjukkan bahwa dari 150 subjek penelitian, terdapat sejumlah 41 siswa (27,33\%) yang rutin memeriksakan giginya ke dokter gigi, dan 109 siswa (72,66\%) yang tidak memeriksakan giginya ke dokter gigi.

\section{Tindakan pencarian pertolongan dokter gigi pada saat sakit gigi}

Data hasil penelitian tentang tindakan pencarian pertolongan dokter gigi pada saat sakit

Hasil penelitian menunjukkan bahwa dari 150 subjek penelitian, terdapat sejumlah 99 siswa (66\%) yang meminta pertolongan dokter/dokter gigi pada saat sakit gigi, dan 51 siswa (34\%) yang tidak melakukan tindakan apa-apa atau hanya dibiarkan saja dengan harapan bisa sembuh sendiri.

Data yang diperoleh secara keseluruhan hasil perhitungan tindakan peningkatan kebersihan gigi dari siswa SD Kristen Eben Haezar 02 Manado yaitu sebagai berikut: junlah jawaban benar yang di jawab oleh siswa untuk 3 pertanyaan mengenai tindakan peningkatan kebersihan gigi yaitu 690. Maka:

$$
\begin{gathered}
\mathrm{X} / 900 \times 100 \%=\mathrm{Y} \\
690 / 900 \times 100 \%=76,67 \%
\end{gathered}
$$

Berdasarkan hasil perhitungan di atas, persentase tindakan peningkatan kebersihan gigi siswa SD Kristen Eben Haezar 02 Manado sebesar 76,67\%. Maka dalam penjabaran pada skala perhitungan tindakan peningkatan kebersihan gigi siswa SD Kristen Eben Haezar 02 Manado termasuk pada kategori baik.

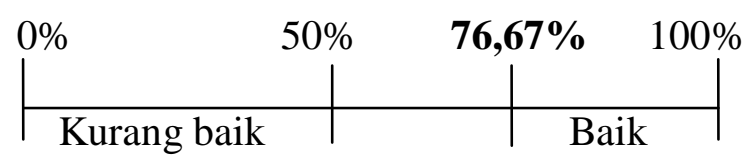


Hasil penelitian ini menunjukan bahwa tindakan pemeliharaan kesehatan gigi dan mulut anak usia 10-12 tahun di SD Kristen Eben Haezar 02 Manado secara keseluruhan yaitu: jumlah jawaban yang benar yang dijawab oleh siswa untuk 10 pertanyaan mengenai tindakan pemeliharaan kesehatan gigi dan mulut adalah 2248 . Maka:

$$
\begin{gathered}
X / 3000 \times 100 \%=Y \\
2248 / 3000 \times 100 \%=74,93 \%
\end{gathered}
$$

Berdasarkan hasil perhitungan di atas, persentase tindakan peningkatan pemeliharaan gigi siswa SD Kristen Eben Haezar 02 Manado sebesar 74,93\%. Maka dalam penjabaran pada skala perhitungan tindakan pemeliharaan kesehatan gigi dan mulut siswa SD Kristen Eben Haezar 02 Manado termasuk pada kategori baik.

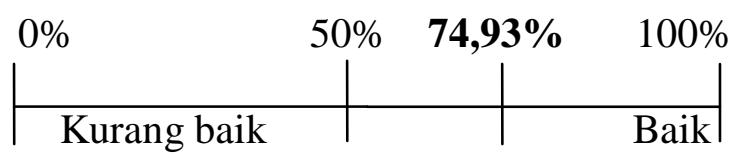

\section{BAHASAN}

Berdasarkan hasil penelitian yang ada, diperoleh gambaran bahwa kira-kira setengah dari subjek penelitian (51,3\%) melakukan tindakan pemeliharaan kebersihan gigi dan mulut yang benar, yakni melakukan penyikatan gigi 2 kali sehari setelah sarapan dan sebelum tidur malam. Hasil ini hampir berimbang dengan tindakan pemeliharaan kebersihan gigi dan mulut yang keliru, yakni 48,6\% melakukan penyikatan gigi 2 kali sehari akan tetapi waktunya kurang tepat. Tindakan penyikatan gigi yang keliru ini dilakukan setelah bangun pagi, yaitu sebelum sarapan dan saat mandi sore atau sebelum makan malam. Kurangnya kesadaran responden dan dukungan orang tua terhadap penyikatan gigi sangat berpengaruh terhadap kesadaran akan pentingnya tindakan menyikat gigi pada waktu yang tepat. Menurut Claessen et al waktu yang tepat untuk menyikat gigi adalah setelah sarapan pagi dan sebelum tidur malam. ${ }^{12}$ Tindakan ini dikatakan tepat karena sesuai dengan tujuan menyikat gigi yakni untuk membersihkan gigi dan mulut dari sisa-sisa makanan yang menempel pada permukaan gigi setelah selesai makan.

Hasil penelitian selanjutnya tentang cara menyikat gigi memperlihatkan hasil sebagian besar subjek penelitian (82\%) menyikat gigi dengan mengombinasikan gerakan ke atas ke bawah dengan gerakan maju mundur, dan gerakan memutar. Gerakan penyikatan untuk rahang bawah arahnya ke atas dan untuk rahang atas arahnya ke bawah, sedangkan untuk permukaan kunyah (oklusal) disikat dengan gerakan maju mundur. Para ahli juga menyimpulkan bahwa cara menyikat gigi yang paling efektif yaitu dengan cara mengombinasikan semua metode yang ada. ${ }^{25}$

Data yang diperoleh dari penelitian tentang permukaan gigi yang disikat, didapatkan hasil bahwa sebagian besar subjek penelitian $(86,66 \%)$ menyikat seluruh permukaan gigi saat melakukan penyikatan gigi, dan hanya sebagian kecil yang menyikat permukaan luar saja atau permukaan dalam saja. Claessen et al menganjurkan untuk menyikat seluruh permukaan gigi saat menyikat gigi. Penyikatan dilakukan selama kira-kira 2 menit agar keseluruhan gigi dapat dibersihkan dengan tepat. Gigi-gigi belakang (posterior) jangan sampai terlewat, karena lubang gigi sebagian besar terjadi pada gigi-gigi geraham yang terletak di bagian belakang.

Penelitian selanjutnya tentang apa yang dilakukan setelah makan makanan yang manis seperti snack, coklat, permen,dll; didapatkan hasil sebagian besar subjek penelitian menyikat gigi setelah makan makanan manis yaitu sebanyak 64 anak (42,7\%). Hasil ini hampir sama dengan subjek penelitian yang berkumur yaitu sebanyak 86 anak (57,3\%). Dilihat dari perolehan hasil yang ada menggambarkan sebagian besar subjek penelitian sudah memiliki tindakan yang benar dalam pemeliharaan kesehatan gigi dan mulut setelah mengonsumsi makanan 
yang manis. Tindakan menyikat gigi sehabis makan makanan manis merupakan tindakan yang ideal, dan itu dimiliki oleh hampir separuh subjek penelitian, sedangkan tindakan berkumur setelah mengonsumsi makanan yang manis merupakan tindakan pemeliharaan yang minimal harus dilakukan. Tindakan ini sudah membantu membersihkan permukaan gigi dari sisa makanan, walaupun belum maksimal.

Hasil penelitian tentang pola konsumsi makanan, meliputi jenis makanan yang dikonsumsi di antara waktu makan dan frekuensi mengonsumsi makanan yang dapat membantu membersihkan gigi. Data yang diperoleh menggambarkan bahwa lebih dari sebagian kecil anak yaitu 21 anak (14\%) mengonsumsi buah-buahan di antara dua waktu makan. Dilihat dari data yang didapatkan, penulis berasumsi bahwa masih banyak subjek penelitian yang belum paham tentang pola makanan yang baik bagi kesehatan gigi. Hal ini tercermin dari jumlah subjek penelitian yang mengonsumsi makanan manis secara bersamaan dengan mengonsumsi buah-buahan. Demikian halnya juga dengan subjek penelitian yang hanya mengonsumsi makanan manis saja. Persentase yang didapat lebih besar dari yang mengonsumsi buah-buahan. Pemahaman yang kurang baik tentang pola makan yang benar akan tercermin pada tindakan dari subjek penelitian tersebut.

Hasil penelitian lainnya yang menilai frekuensi konsumsi buah-buahan, didapatkan hasil bahwa jumlah anak yang sering mengonsumsi buah-buahan (42\%) dan yang jarang mengonsumsi (58\%) perolehan hasilnya hampir berimbang. Hasil yang diperoleh masih menunjukkan bahwa pola konsumsi buah-buahan masih kurang baik.

Perolehan hasil tentang frekuensi mengonsumsi sayuran, menunjukkan bahwa sebanyak 80 anak atau lebih dari separuh anak (53,33\%) sering mengonsumsi sayuran, dimana sayuran dikonsumsi lebih dari 3 kali dalam seminggu. Hasil ini menunjukkan gambaran tindakan pemeliharaan kesehatan gigi yang cukup baik. Konsumsi sayuran dapat membantu pembersihan permukaan gigi dari sisa makanan yang menempel, oleh karena serat yang terdapat pada sayuran secara tidak langsung berfungsi sebagai pembersih permukaan gigi saat mengunyah makanan.

Gambaran hasil penelitian yang memperlihatkan tindakan menjaga kesehatan gigi dan mulut lewat penggunaan pasta gigi mengandung fluor menunjukkan hasil bahwa seluruh anak (100\%) menggunakan pasta gigi mengandung fluor saat menyikat gigi. Walaupun data yang ada menunjukkan hasil yang sempurna bahwa subjek penelitian telah memiliki tindakan tersebut, namun hal ini belum menjamin bahwa seluruh subjek telah betul-betul memahami akan tindakan ini. Mungkin saja subjek baru pada tahap meniru perilaku yang ada dalam keluarga, akan tetapi secara pribadi belum memahami secara benar akan manfaat dari tindakan yang dilakukan. Subjek mungkin belum memahami manfaat penambahan fluor dalam pasta gigi, karena semua pasta gigi yang beredar di Indonesia saat ini sudah mengandung fluor. Di samping itu pada anak usia 10 -12 tahun, belum memiliki inisiatif menyediakan sendiri pasta gigi yang akan digunakan, namun masih sepenuhnya bergantung pada apa yang sudah disediakan orangtua di rumah.

Hasil penelitian berikutnya tentang kunjungan rutin ke dokter gigi dalam setahun, memperlihatkan bahwa sebagian besar subjek penelitian, yakni 109 anak (72,66\%) anak tidak pernah memeriksakan diri ke dokter gigi secara rutin untuk kontrol, dan hanya 41 anak (27,33\%) yang secara rutin dua kali dalam setahun memeriksakan giginya ke dokter gigi. Hasil yang ada merupakan perwujudan gambaran perilaku yang dimiliki oleh orang tua si anak. Dalam hal kunjungan rutin ke dokter gigi, biasanya anak masih bergantung pada orangtua. Dengan demikian apa yang menjadi perilaku orangtua akan diwujudnyatakan pada tindakan yang akan dilakukan pada si anak.

Gambaran hasil penelitian yang memperlihatkan tentang apa yang dilakukan pada saat sakit gigi, didapatkan hasil bahwa sebagian besar subjek 
penelitian yaitu 99 anak (66\%) meminta pertolongan dokter atau dokter gigi pada saat sakit gigi. Keadaan ini menggambarkan tindakan yang dimiliki orangtua terutama ibu apabila anaknya sakit. Tindakan yang dilakukan oleh si anak merupakan perwujudan tindakan yang dimiliki sang ibu.

Menurut Sarwono yang dikutip oleh E.R Widi, salah satu faktor yang memengaruhi tingkat kebersihan gigi dan mulut adalah faktor perilaku. Perilaku adalah suatu bentuk pengalaman dan interaksi individu dengan lingkungannya, khususnya yang menyangkut pengetahuan dan sikap tentang kesehatan serta tindakannya yang berhubungan dengan kesehatan. Faktor yang terpenting dalam usaha menjaga kebersihan gigi dan mulut adalah faktor kesadaran dan perilaku pemeliharaan kesehatan gigi dan mulut secara personal karena kegiatannya dilakukan di rumah tanpa ada pengawasan dari siapapun, sepenuhnya tergantung dari pengetahuan pemahaman, kesadaran serta kemauan pihak individu untuk menjaga kebersihan mulutnya. ${ }^{13}$

\section{SIMPULAN DAN SARAN}

Berdasarkan hasil penelitian dan pembahasan maka dapat ditarik kesimpulan bahwa:

1. Tindakan pemeliharaan kesehatan gigi dan mulut anak usia $10-12$ tahun SD Eben Haezar 02 Manado, mencakup tindakan pemeliharaan kebersihan gigi dan mulut, pola konsumsi makanan, dan tindakan peningkatan kesehatan gigi dan mulut; rata-rata tergolong baik.

2. Tindakan pemeliharaan kebersihan gigi dan mulut anak usia $10-12$ tahun SD Eben Haezar 02 Manado, mencakup frekuensi dan waktu menyikat gigi, cara menyikat gigi, dan tindakan yang dilakukan setelah makan makanan manis; rata-rata tergolong baik.

3. Pola makan anak usia $10-12$ tahun SD Eben Haezar 02 Manado, mencakup jenis makanan yang dikonsumsi di antara dua waktu makan, frekuensi konsumsi makanan yang membantu membersihkan gigi; rata-rata tergolong baik.

4. Tindakan peningkatan kesehatan gigi dan mulut anak usia $10-12$ tahun SD Eben Haezar 02 Manado, mencakup tindakan penggunaan pasta gigi mengandung fluor, tindakan kontrol rutin ke dokter gigi dalam setahun, serta tindakan pencarian pertolongan dokter gigi saat sakit; rata-rata tergolong baik.

\section{DAFTAR PUSTAKA}

1. Kawuryan U. Hubungan pengetahuan tentang kesehatan gigi dan mulut dengan kejadian karies gigi anak. 2008 [dikutip 21 Mei 2011]; Available from: URL: http://etd.eprints.ums.ac.id/897/1/J21004000 6.pdf

2. Riyanti E, Saptarini R. Upaya peningkatan kesehatan gigi dan mulut melalui perubahan perilaku anak. Fakultas Kedokteran Gigi Universitas Padjajaran. 2009 [cited 2011 Jan 20]; Available from: URL: http:/www.scribd.com.

3. Mostofsky DI, Forgione AG, Giddo DB, editors. Behavioral dentistry. New York: Blackwell Munksgaard, 2006. p. 19-26.

4. Pintauli S, Hamada T. Menuju gigi dan mulut sehat. Medan: USU Press, 2008: 4-8, 74-75, 79-81.

5. Angela A. Pencegahan primer pada anak beresiko karies tinggi. Dent J 2005: 38 (3): 130,132-133.

6. Vallejos-Sánchez AA, Medina-Solís CE. Sociobehavioral factors influencing toothbrushing frequency among schoolchildren. J Am Dent Assoc (JADA): 2008; 743-749.

7. Notoatmodjo S. Promosi kesehatan teori dan aplikasi. Jakarta : Penerbit Rineka Cipta ; 2005. p. 45-55.

8. Warni L. Hubungan perilaku murid SD kelas V dan VI pada kesehatan gigi dan mulut terhadap status karies gigi di wilayah kecamatan Delitua kabupaten Deli Serdang. Fakultas Kesehatan Masyarakat Universitas Sumatera Utara. 2009.

9. Bachtiar B, Wimardhani YS, editors. The impact of oral health problem on school children. KPPIKG 2009. Proceedings of the $15^{\text {th }}$ Scientific Meeting and Refresher Course in Dentistry; 14-17 Oktober 2009; Jakarta Convention Center. Jakarta: Sagung 
706 Jurnal e-Biomedik (eBM), Volume 1, Nomor 1, Maret 2013, hlm. 697-706

Seto; 2009; p. 226- 230.

10.Profil Kesehatan Sulawesi Utara 2007. Oktober 2009 [dikutip 5 Januari 2013]; available from: URL: http://www.depkes. go.id/downloads/profil/prov_sulut_2007.pdf

11.Riduwan. Dasar-dasar statistika; Dr. Prana Dwija Iswara, editor, pengantar : Prof. Dr. H. Moch. Idochi Anwar, M.Pd -Cet.3Bandung: Alfabeta 2003
12.Claessen, dkk. Designing interventions to improve tooth brushing. International Dental Journal, 2008; 58: 307-20.

13.Widi ER. Hubungan perilaku membersihkan gigi terhadap tingkat kebersihan mulut siswa sekolah dasar negeri wilayah kerja puskesmas gladak pakem kabupaten jember. JKGI 2003; 10 (3): $10 ; 13$. 